
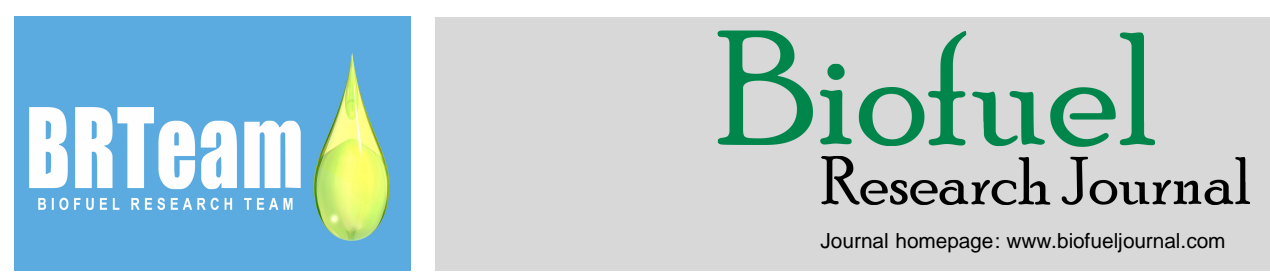

Journal homepage: www.biofueljournal.com

Original Research Paper

\title{
Surfactant-assisted direct biodiesel production from wet Nannochloropsis occulata by in situ transesterification/reactive extraction
}

\author{
Kamoru A. Salam *, Sharon B. Velasquez-Orta , Adam P. Harvey \\ School of Chemical Engineering and Advanced Materials (CEAM), Newcastle University, NE1 7RU, United Kingdom.
}

\section{HIGHLIGHTS}

$>$ Surfactant assisted in situ transesterification of wet algae was studied.

$>$ A surfactant catalyst ("ZDS") produced high yields

in Nannochloropsis occulata.

$>$ Inclusion of SDS in $\mathrm{H}_{2} \mathrm{SO}_{4}$ increased FAME

production in the wet algae.

$>$ The process was not adversely affected by water in the algae up to $20 \%$.

\section{GRAPHICAL ABSTRACT}

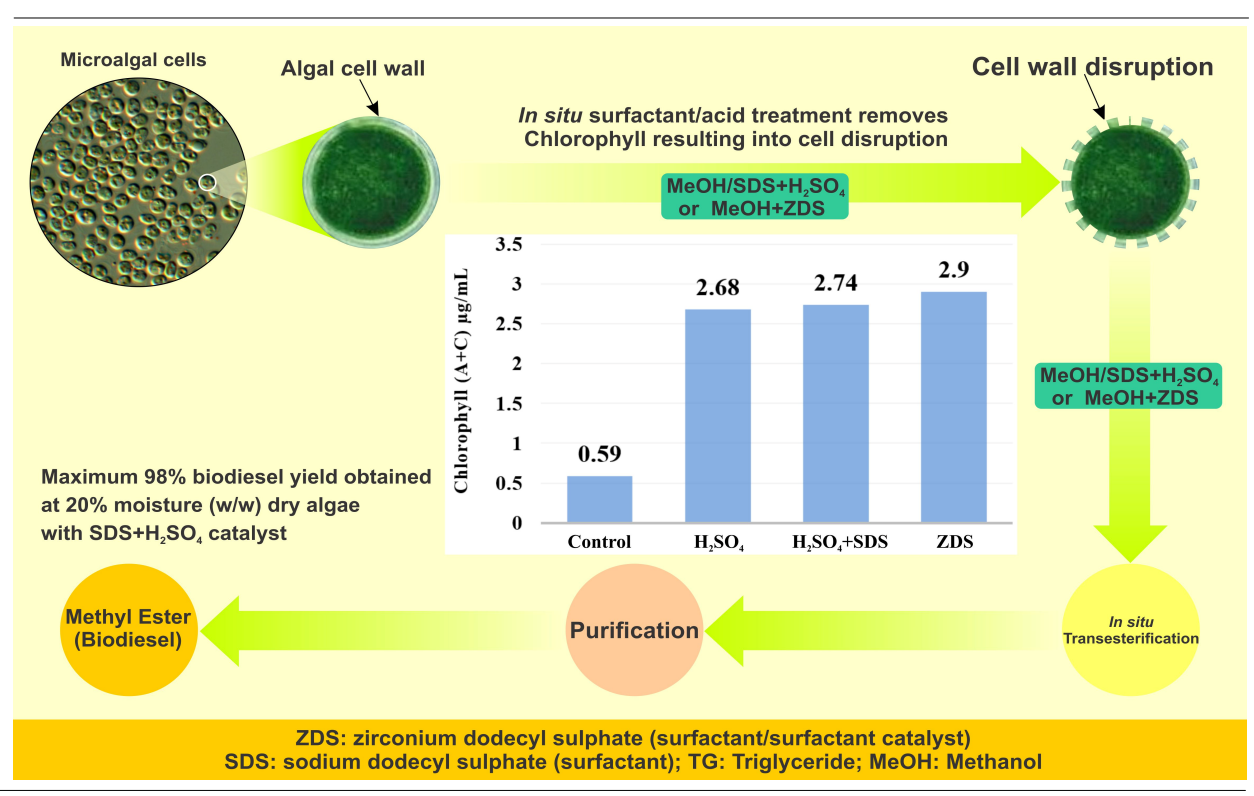

\section{ARTICLE INFO}

\section{Article history:}

Received 9 September 2015

Received in revised form 20 November 2015

Accepted 11 December 2015

Available online 1 March 2016

\section{Keywords:}

Wet microalgae

Reactive extraction

Biodiesel (Fatty acid methyl ester)

Surfactant

Surfactant catalyst

\begin{abstract}
This article reports an in situ transesterification/reactive extraction of Nannochloropsis occulata for fatty acid methyl ester (FAME) production using $\mathrm{H}_{2} \mathrm{SO}_{4}$, sodium dodecyl sulphate (SDS) plus $\mathrm{H}_{2} \mathrm{SO}_{4}$ and zirconium dodecyl sulphate (ZDS). A maximum $67 \%$ FAME yield was produced by ZDS. Effect of inclusion of sodium dodecyl sulphate (SDS) in $\mathrm{H}_{2} \mathrm{SO}_{4}$ for FAME enhancement and water tolerance was also studied by hydrating the algae with $10 \%-30 \%$ distilled water (w/w) dry algae. Treatment with SDS in $\mathrm{H}_{2} \mathrm{SO}_{4}$ increases the FAME production rate and water tolerance of the process. Inclusion of SDS in $\mathrm{H}_{2} \mathrm{SO}_{4}$ produced a maximum $98.3 \%$ FAME yield at $20 \%$ moisture in the algae. The FAME concentration began to diminish only at $30 \%$ moisture in the algae. Furthermore, the presence of a small amount of water in the biomass or methanol increased the lipid extraction efficiency, improving the FAME yield, rather than inhibiting the reaction.
\end{abstract}

* Corresponding author at: Tel.: +447425921464

E-mail address: kamorusalam@gmail.com; kamoru.salam@ncl.ac.uk

Please cite this article as: Salam K.A., Velasquez-Orta S.B., Harvey A.P. Effect Surfactant-assisted direct biodiesel production from wet Nannochloropsis occulata by in situ transesterification/reactive extraction. Biofuel Research Journal 9 (2016) 366-371. DOI: 10.18331/BRJ2016.3.1.6 


\section{Introduction}

The need to produce alternative renewable transport fuels has generated considerable global interest in biodiesel (Meng et al., 2009). Consequently, different biodiesel feedstocks have been explored, including food oil crops (Zeng et al., 2008), non-food oil crops such as Jatropha curcas (Kasim and Harvey, 2011), and microalgae (Wahlen et al., 2011; Velasquez-Orta et al., 2012). Food oil crops are not sustainable, as freshwater and considerable hectares of arable land are required for their cultivation (Chisti, 2007). On the other hand, non-food oil crops and waste oil can only supply limited quantities of biofuels, so cannot meet world transport fuels requirements.

There are still a number of challenges for algae to be used as fuel feedstocks including limited supply of concentrated $\mathrm{CO}_{2}$, full utilisation of nitrogen or phosphorous nutrients, adverse effect of small quantity of fresh water even if marine algae is used, and efficient utilisation of algal residues after oil extraction (Chisti, 2013). Additionally, economic construction of large algae photobioreactors, and reducing the drying costs, perhaps by increasing the water tolerance of the reaction step need to be done for micro algal biodiesel to become a commercial reality. Regardless of these challenges, microalgae could still serve as alternative biodiesel feedstock as it has short growing time, high lipid productivity while it is capable of capturing concentrated $\mathrm{CO}_{2}$ and can potentially be used in waste water remediation.

Biodiesel can be made either by reactive extraction ("in situ transesterification") (Wahlen et al., 2011; Velasquez-orta et al., 2012) or by two step transesterification of pre-extracted oil (Eze et al., 2014). A major advantage of in situ transesterification over the two step transesterification is that it reduces the number of process steps (by eliminating the solvent extraction steps) by contacting the biomass directly with the reactants. This could reduce the cost of biodiesel production. However, the major drawback of in situ transesterification is that it requires a high molar ratio of methanol to oil. The need to recycle the unreacted methanol (over $94 \%$ of it) increases the process costs. Additionally, extraction of intracellular lipids from microalgae requires a significant excess of solvent because of the chemical resistance and structural toughness of algal cell walls (Gerken et al., 2012).

The relatively low permeability of polar solvents such as methanol and ethanol, as well as non-polar solvents such as hexane through the walls of dried oil-bearing cells can significantly reduce lipid extraction effectiveness, but it can be improved by addition of a small amount of water (Cohen et al., 2012). The water swells the cellular structure of polysaccharide-containing biomass, which increases the solvent permeability through the cell walls (Cohen et al., 2012). Similarly, the inclusion of water in alcohol such as methanol or ethanol was effective for extraction of polar lipids such as phospholipids or glycolipids (Zhukov and Vereshchagrin, 1981). Polar lipids are the major components of algal cell walls. Their removal from micro algal cell walls compromises their integrity, which can improve fatty methyl ester (FAME) recovery during in situ transesterification.

The most common homogeneous catalysts for in situ transesterification of microalgae are $\mathrm{NaOH}$ and $\mathrm{H}_{2} \mathrm{SO}_{4}$. $\mathrm{NaOH}$ is seldom used in microalgae if its lipids contain high free fatty acid (FFA) perhaps due to long term storage (Chen et al., 2012) to prevent soap formation (Canakci and Gerpen, 1999; Ma and Hanna, 1999). When $\mathrm{H}_{2} \mathrm{SO}_{4}$ is used, a high concentration of the catalyst is always required to achieve high yields (Wahlen et al., 2011; Velasquez-Orta et al., 2013). However, the need to neutralise the unreacted acid in the product streams will increase operating costs.

A surfactant catalyst (cerium (III) trisdodecyl trihydrate) has been evaluated for a two-step FAME production from soybean oil and oleic acid (Ghesti et al., 2009). The authors concluded that the surfactant catalyst efficiently promoted the transesterification of triglycerides and the esterification of free fatty acids. Similarly, use of cetyltrimethylammonium bromide (CTAB) (a cationic surfactant) with an alkali catalyst resulted in an increased FAME yield and reduction in catalyst concentration during in situ transesterification of Jatropha curcas by acting as a phase transfer catalyst (Hailegiorgis et al., 2011).

Park et al. (2014) reported that inclusion of sodium dodecyl benzene sulfonate (SDBS) in $\mathrm{H}_{2} \mathrm{SO}_{4}$-catalysed hot water enhanced extraction of FFA and lipids from Chlorella vulgaris. They reported that the inclusion of SDBS in $\mathrm{H}_{2} \mathrm{SO}_{4}$ significantly reduced the amount of $\mathrm{H}_{2} \mathrm{SO}_{4}$ required to convert the pre-extracted algal oil into FAME using a two-step transesterification. Inclusion of sodium dodecyl sulphate (SDS) in water has also been reported to increase oil extraction from canola seeds (Tuntiwiwattanapun et al., 2015).
In a different study, SDS has been used for lysing cells to recover intracellular components (Brown and Audet, 2008).

Effect of inclusion of SDS in $\mathrm{H}_{2} \mathrm{SO}_{4}$ for a direct FAME production from wet microalgae has not been investigated. Similarly, an in situ transesterification of microalgae by a surfactant catalyst has not been reported in the literature. Therefore, this paper reports on the usage of zirconium dodecyl sulphate ("ZDS") (a surfactant catalyst) to catalyse in situ transesterification of Nannochloropsis occulata. Cell wall disruption by ZDS was explored for FAME enhancement.

In addition, the inclusion of SDS in $\mathrm{H}_{2} \mathrm{SO}_{4}$ was used in this report for improving water tolerance of the in situ transesterification of $N$. occulata. This is entirely a new approach to produce biodiesel from wet microalgae through in situ transesterification. It is worth quoting that even small amounts of water have been reported to significantly decrease conversion during a two-step transesterification of vegetable oil (Canakci and Gerpen, 1999). On the other hand, complete drying of algae is energy intensive, which significantly increases the cost of algae pre-treatment. Hence, the findings of the present study are important, as the significant amounts of energy required to dry microalgal biomass or microalgal oil to the levels required in a two-step biodiesel production render the process uneconomic, and is currently one of the major technical challenges to micro algal biodiesel production.

\section{Materials and methods}

\subsection{Microalgae culture and their major biochemical compositions}

Concentrated wet $N$. occulata was purchased from Varicon Aqua Solutions (London, UK). Guldhe et al. (2014) has shown that there was no significant differences in the lipid extraction yield of Scenedesmus sp. dried by three techniques: freeze-drying, oven- drying, and sun-drying. Therefore, a frozen sample was freeze-dried at $-40^{\circ} \mathrm{C}$ for $\sim 24 \mathrm{~h}$ in a Thermo Modulyo D Freeze Dryer as this method is faster than the other drying techniques. A moisture analyser was used to further dry the algae at $60^{\circ} \mathrm{C}$ to preserve its biochemical compositions (Widjaja et al., 2009) until their moisture remained constant. The moisture content of the resulting dry microalgae was taken as $0 \%$ (w/w dry algae). The total lipids content were measured using the method described by Folch et al. (1956). The FFA and cell wall lipids (phospholipids and glycolipids) of the species were measured using the solid phase extraction method of Kaluzny et al. (1985).

\subsection{Determination of maximum FAME content}

The maximum FAME concentration was quantified using the procedure described by Garces and Mancha (1993). A methylating mixture of methanol, toluene, 2,2-dimethoxypropane, and sulphuric acid at a volumetric ratio of 39:20:5:2 was prepared. The mixture was thoroughly mixed using a vortex mixer. A homogeneous mixture containing $3.3 \mathrm{~mL}$ of the methylating mixture and $1.7 \mathrm{~mL}$ of heptane was added to $0.2 \mathrm{~g}$ microalgae and vortexed well. After this, the mixture was transesterified in an IKA incubator at $60^{\circ} \mathrm{C} ; 450 \mathrm{rpm}$ for $12 \mathrm{~h}$. Subsequently, the acid catalyst was neutralised with calcium oxide $(\mathrm{CaO})$ to quench the reaction. The resulting upper FAME layer was carefully pipetted into a pre-weighed centrifuge tube and weighed. After that, it was prepared for FAME analysis and its concentration was measured by gas chromatography. The maximum FAME content in the sample was calculated by multiplying the FAME concentration obtained by the mass of the upper FAME layer.

\subsection{Catalyst synthesis}

Zirconium (IV) dodecyl sulphate $\left(\mathrm{Zr}\left[\mathrm{OSO}_{3} \mathrm{C}_{12} \mathrm{H}_{25}\right]_{4}\right)$ was synthesised using the modified method presented by Zolfigol et al. (2007) as follows by inclusion of $4 \% \mathrm{KCl}$ (w/w zirconium dodecyl sulphate solution):

(i) $2.86 \mathrm{~g}(8.9 \mathrm{mmol})$ of zirconium oxychloride octahydrate (Sigma Aldrich, UK) was dissolved in $100 \mathrm{ml}$ of distilled water at room temperature; 
(ii) $12.13 \mathrm{~g}$ (42 mmol) of sodium dodecyl sulphate (VWR, UK) was put in a three-neck $500 \mathrm{ml}$ round bottom flask. Then, $300 \mathrm{ml}$ of distilled water was added to this at room temperature;

(iii) A zirconium oxychloride octahydrate solution was added to the sodium dodecyl sulphate solution whilst mixing at $500 \mathrm{rpm}$ and stirred for 30 $\min$;

(iv) $4 \% \mathrm{KCl}$ (w/w zirconium dodecyl sulphate solution) was added to increase catalyst recovery;

(v) The precipitate was centrifuged and washed repeatedly with $150 \mathrm{~mL}$ distilled water;

(vi) The resulting white solid was further calcined at $80^{\circ} \mathrm{C}$ for $4 \mathrm{~h}$ and was then dried in a desiccator (Duran vacuum desiccator).

\subsection{Quantification of cell disruption after in situ transesterification}

The amount of chlorophyll extracted from the microalgae has been correlated with cell wall disruption by Gerde et al. (2012). The total chlorophyll $\mathrm{A}$ and $\mathrm{C}$ obtained after the in situ transesterification by the different catalysts was measured using a modified version of the method previously described by Gerde et al. (2012). To study the extent of cell disruption in $N$. occulata, $0.47 \mathrm{~mL}$ of methanol was added to a $100 \mathrm{mg}$ of dried microalgae in a $2.5 \mathrm{~mL}$ tube followed by the addition of $100 \% \mathrm{H}_{2} \mathrm{SO}_{4}$ (w/w oil). To another tube containing the same amount of microalgae, methanol, $\mathrm{H}_{2} \mathrm{SO}_{4}$, and $9 \mathrm{mg}$ SDS was added to study the effect on cell disruption by including SDS in $\mathrm{H}_{2} \mathrm{SO}_{4}$. A third test tube was used with $100 \%$ ZDS (w/w lipids), $100 \mathrm{mg}$ of microalgae, and $0.47 \mathrm{~mL}$ of methanol. The reactions were allowed to progress for $24 \mathrm{~h}$, at $32^{\circ} \mathrm{C}$ to avoid degradation of the chlorophyll at a stirring rate of $450 \mathrm{rpm}$ using IKA KS 4000 icontrol incubator shaker (IKA, Germany). At the end of the reaction, the samples were centrifuged at $17,000 \times \mathrm{g}$ for $10 \mathrm{~min}$ using an Accu Spin Micro 17 centrifuge (Fisher Scientific, UK). Methanol was used as blank. The absorbance of the supernatant obtained was measured at 664, 647, and 630 $\mathrm{nm}$ and the chlorophyll concentrations in $\mu \mathrm{g} / \mathrm{mL}$ were calculated using the formulae presented by Jeffrey and Humphrey (1975) (Eqs. 1 and 2):

Chla $=11.93 A_{664}-1.93 A_{647}$

Chlc $=-3.73 A_{664}+24.36 A_{630}$

Eq. 2

Where Chla is chlorophyll a and Chlc is chlorophyll c.

\subsection{Experimental designs}

An 8.5 mol. $\mathrm{H}_{2} \mathrm{SO}_{4} /(\mathrm{mol}$. lipids) which equals to $100 \%$ (w/w lipids) was used. ZDS was fixed as $100 \% \mathrm{ZDS}$ (w/w lipids). These amounts of catalysts used in this study were based on the optimum of $100 \% \mathrm{H}_{2} \mathrm{SO}_{4}$ (w/w oil) reported by Ehimen et al. (2010).

A $9 \mathrm{mg}$ of SDS was added to $\mathrm{H}_{2} \mathrm{SO}_{4}$ to study the effect of combination of a surfactant and homogeneous $\mathrm{H}_{2} \mathrm{SO}_{4}$ catalyst on FAME yield. This amount of SDS was significantly greater than $2 \mathrm{~mol}$. SDS/(mol. oil) reported to be enough to solubilise the phospholipid bilayer (Tan et al., 2002). The molar ratio of methanol to lipid was $600: 1$, which equals to $0.0047 \mathrm{~mL} /(\mathrm{mg}$ algae cells). A temperature of $60^{\circ} \mathrm{C}$ was used for all the experiments as most previous reports on in situ transesterification of microalgae were optimised at $60^{\circ} \mathrm{C}$ (Haas and Wagner, 2011; Li et al., 2011; Velasquez-Orta et al., 2013). An $880 \mathrm{~g} /(\mathrm{mol}$.) was the average molecular mass of the oil used to calculate the entire molar ratios. Rehydrated samples of $N$. occulata were prepared by adding $10 \%, 20 \%$, and $30 \%$ of distilled water (w/w dry algae), then allowing the samples to equilibrate for $1 \mathrm{~h}$. The resulting wet biomass was then transesterified using $\mathrm{H}_{2} \mathrm{SO}_{4}$, with or without SDS, to isolate the water tolerance effect.

All in situ transesterification were conducted in $15 \mathrm{~mL}$ glass tubes containing $100 \mathrm{mg}$ of microalgae. The tubes were loaded in an IKA KS 4000 icontrol incubator shaker (IKA, Germany) and kept at a constant temperature of $60^{\circ} \mathrm{C}$. A high stirring rate of $450 \mathrm{rpm}$ was used to prevent mass transfer limitations. The acid catalyst in each sample taken at each specified in situ transesterification was neutralised with $\mathrm{CaO}$ to quench the reaction. The biomass was separated from the liquid by centrifugation. The biodiesel filtrate (a mixture of methanol, FAME, and by-products) was stored in pre-weighed tubes and weighed. The FAME concentration in the biodiesel filtrate was measured by gas chromatography, as explained in the Section 2.6.

\subsection{Analytical techniques}

The Standard UNE-EN 14103 (2003) was used to determine the FAME concentration after the in situ transesterification. The biodiesel filtrate was mixed with $0.1 \mathrm{~mL}$ of an internal standard solution: methyl heptadecanoate (Sigma Aldrich, UK, $10 \mathrm{mg} /(\mathrm{mL}$ methanol) in $2 \mathrm{~mL}$ vials. Then, $1 \mu \mathrm{L}$ of the homogeneous mixture was injected into the $\mathrm{GC}$ and data was collected using the Data Apex Clarity software (UK). The gas chromatograph was operated at the following conditions: carrier gas: helium, 7 psi; air pressure, 32 psi; hydrogen pressure, 22 psi, and capillary column head pressure, $4.5 \mathrm{psi}$. The carrier gas flow rate was $2 \mathrm{~mL} / \mathrm{min}$. The oven temperature was maintained at $230^{\circ} \mathrm{C}$ for $25 \mathrm{~min}$. Heat rate was $15^{\circ} \mathrm{C} / \mathrm{min}$; initial temperature was set at $150^{\circ} \mathrm{C}$ and held for $2 \mathrm{~min}$; final temperature was set at $210^{\circ} \mathrm{C}$ and held for $20 \mathrm{~min}$; injection temperature was $250^{\circ} \mathrm{C}$ while detector temperature was $260^{\circ} \mathrm{C}$. The column used was CP WAX 52 CB $30 \mathrm{~m} \times 0.32 \mathrm{~mm}(0.25 \mu \mathrm{m})$ (Agilent, Netherlands). The mass of FAME obtained in the biodiesel-rich phase from the experiments was calculated by multiplying the mass of the final biodiesel mixture obtained and the FAME concentration measured by the GC. The FAME yield was calculated by dividing the mass of FAME obtained by the maximum FAME available in the algae (Eq. 3).

FAME Concentration $(\mathrm{C})=\frac{\left(\sum A\right)-A_{E i}}{A_{E i}} \times \frac{C_{E i} V_{E i}}{m} \times 100 \%$

Where $\sum A$ is the total peak areas from $\mathrm{C} 12-\mathrm{C} 20: 1, A_{E i}$ is the peak area of the methyl heptadecanoate, $V_{E i}$ stands for the volume in $\mathrm{ml}$ of the methyl heptadecanoate used, $C_{E i}$ is the concentration in $\mathrm{mg} /(\mathrm{mL}$ of the methyl heptadecanoate solution), and $m$ is the mass of the sample in mg.

The mass of the methyl ester in the sample was calculated by multiplying the FAME concentration (C) by the mass of the biodiesel filtrate from the in situ transesterification (Eq. 4).

Mass of the methyl ester $(\mathrm{mg})=\mathrm{C}(\%) \times \mathrm{w}(\mathrm{mg})$

Eq. 4

Where $\mathrm{w}$ is the mass of the biodiesel filtrate.

Yield $(\% \mathrm{w} / \mathrm{w})$ was the determined by comparing the mass of methyl ester obtained with the maximum FAME in the sample as follows (Eq. 5):

Yield $(\% \mathrm{w} / \mathrm{w})=\frac{\text { Mass of methyl ester from the experiments }(\mathrm{mg})}{\text { Mass of the maximum FAME in the sample }(\mathrm{mg})} \times 100 \%$ Eq.5

\section{Results and discussion}

\subsection{In situ transesterification using $\mathrm{H}_{2} \mathrm{SO}_{4}$}

The amount of total lipids was determined as $17 \pm 0.8 \%$ (w/w dry algae) while the FFAs were determined as $18.3 \pm 2.4 \%$ (w/w total lipids).This level of FFA necessitates the use of acid rather than base catalysts. Lotero et al. (2005) reported an upper limit of $0.5 \%$ FFA content to prevent saponification for two-step alkali-catalysed transesterification. Figure 1 shows that the FAME yield increased with increasing the reaction time as expected. The maximum FAME yield was $53.8 \pm 8 \%$ occurring at $24 \mathrm{~h}$

Increasing the acid concentration to $0.15 \mu \mathrm{L} /(\mathrm{mg}$ algae) resulted in increased FAME yield from 53 to $87 \%$, in $24 \mathrm{~h}$. El-shimi et al. (2013) observed a $53 \%$ increase in FAME yield during $\mathrm{H}_{2} \mathrm{SO}_{4}$-catalysed in situ transesterification of Spirulina platensis by increasing acid volume from 0.0016 to $0.19 \mu \mathrm{L} /(\mathrm{mg}$ algae). Other researchers also reported increases in the yield of biodiesel with an increase in acid concentration during acidcatalysed in situ transesterification of microalgae (Wahlen et al., 2011; Velasquez-Orta et al., 2013). One reason for this is that acids can be involved in other reactions, such as hydrolysis of carbohydrates during acid-catalysed in situ transesterification as well. Consequently, higher acid concentrations may be required to achieve high FAME yields. 


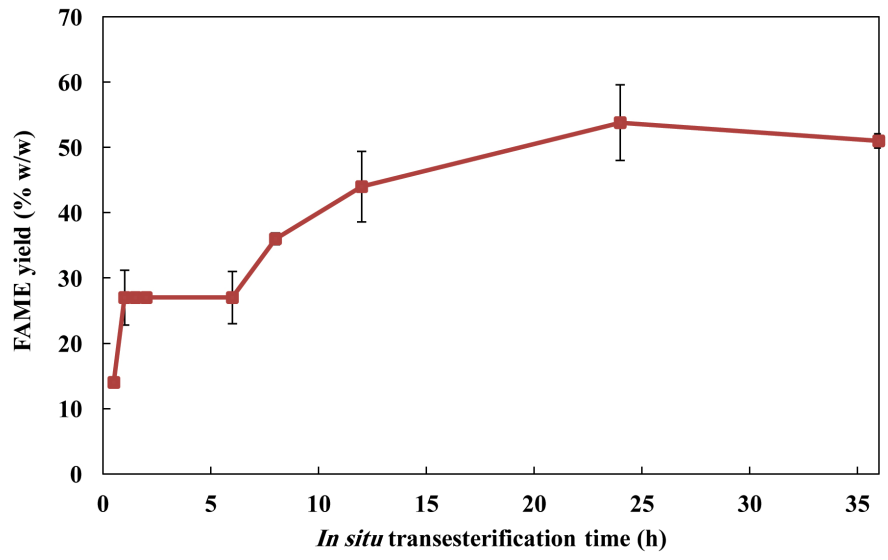

Fig.1. Reactively extracted FAME profile of Nannochloropsis occulata with $\mathrm{H}_{2} \mathrm{SO}_{4}$ catalyst. Process conditions: $600 \mathrm{~mol}$ methanol $/(\mathrm{mol} \mathrm{lipids})=0.47 \mathrm{~mL}$ methanol $/(\mathrm{mg}$ algae $)$, agitation rate $=450 \mathrm{rpm}$, temperature $=60^{\circ} \mathrm{C}$, mass of microalgae $=100 \mathrm{mg}, 8.5 \mathrm{~mol} \mathrm{H}_{2} \mathrm{SO}_{4} /$ (mol lipids) $=0.087 \mu \mathrm{L} /$ (mg biomass).

\subsection{In situ transesterification using $\mathrm{SDS} / \mathrm{H}_{2} \mathrm{SO}_{4}$}

The total amount of phospholipids and glycolipids in the $N$. occulata was determined as $50 \pm 0 \%$ (w/w total lipids). A $3.2 \mathrm{~mol} \mathrm{SDS} /($ mol lipids) was added to $\mathrm{H}_{2} \mathrm{SO}_{4}$ to study its effect on FAME enhancement. As mentioned earlier, this amount of SDS in $\mathrm{H}_{2} \mathrm{SO}_{4}$ was significantly greater than $2 \mathrm{~mol}$ $\mathrm{SDS} /$ (mol phospholipids) required to effectively solubilise the phospholipids bilayers as reported by Tan et al. (2002). The effect of the inclusion of SDS in $\mathrm{H}_{2} \mathrm{SO}_{4}$ on FAME yields for $N$. occulata is shown in Figure 2.

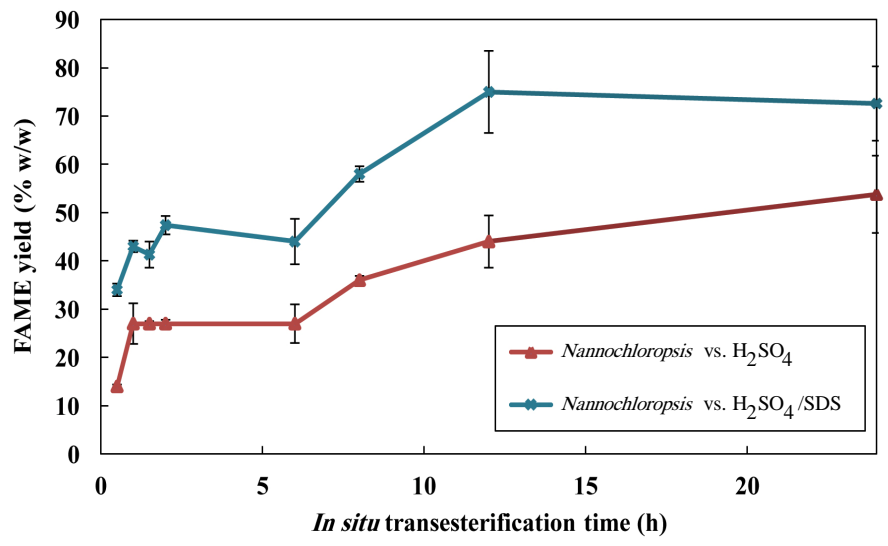

Fig.2. Reactively extracted FAME profile of Nannochloropsis occulata with $\mathrm{H}_{2} \mathrm{SO}_{4}$ vs. SDS plus $\mathrm{H}_{2} \mathrm{SO}_{4}$. Process conditions: $600 \mathrm{~mol}$ methanol $/(\mathrm{mol} \mathrm{lipids})=0.47 \mathrm{~mL}$ methanol $/(\mathrm{mg}$ algae $)$, $8.5 \mathrm{~mol} \mathrm{H} 2 \mathrm{SO} 4 /(\mathrm{mol}$ lipids $)=0.087 \mu \mathrm{L} /(\mathrm{mg}$ algae $)$, agitation rate $=450 \mathrm{rpm}$, temperature $=$ $60^{\circ} \mathrm{C}$, mass of microalgae $=100 \mathrm{mg}$.

It can be seen clearly in the figure that the inclusion of SDS in $\mathrm{H}_{2} \mathrm{SO}_{4}$ caused higher FAME yields compared with the $\mathrm{H}_{2} \mathrm{SO}_{4}$ alone at each data point. At $24 \mathrm{~h}$, a $72.6 \pm 7.7 \%$ maximum FAME yield was obtained using $\mathrm{H}_{2} \mathrm{SO}_{4} / \mathrm{SDS}$ while a $53.8 \pm 8 \%$ FAME yield was obtained in this species at the same duration with $\mathrm{H}_{2} \mathrm{SO}_{4}$ alone. This FAME yield represents $35 \%$ increase. This is significantly higher than the $11 \%$ increase obtained by the inclusion of cetyltrimethylammonium bromide (CTAB) (a surfactant) in $\mathrm{NaOH}$ for in situ ethanolysis of Jatropha curcas L (Hailegiorgis et al., 2011), it is difficult to attribute this to the effect of surfactant though, given the different catalysts used.

\subsection{In situ transesterification with surfactant catalyst ("ZDS”) vs. $\mathrm{H}_{2} \mathrm{SO}_{4}$}

The performance of the synthesized "surfactant catalyst" (zirconium dodecyl sulphate, or "ZDS") for FAME production from $N$. occulata was compared with the FAME yield obtained using $\mathrm{H}_{2} \mathrm{SO}_{4}$ alone as shown in Figure 3.

As can be seen in the figure, the FAME yield produced by both catalysts increased with increases in time as expected. FAME production rate by the ZDS was greater than that produced by $\mathrm{H}_{2} \mathrm{SO}_{4}$ between 12-36 h. This result shows that in situ transesterification of $N$. occulata could be catalysed by ZDS and that ZDS performed more efficiently than the conventional homogeneous $\mathrm{H}_{2} \mathrm{SO}_{4}$ catalyst.

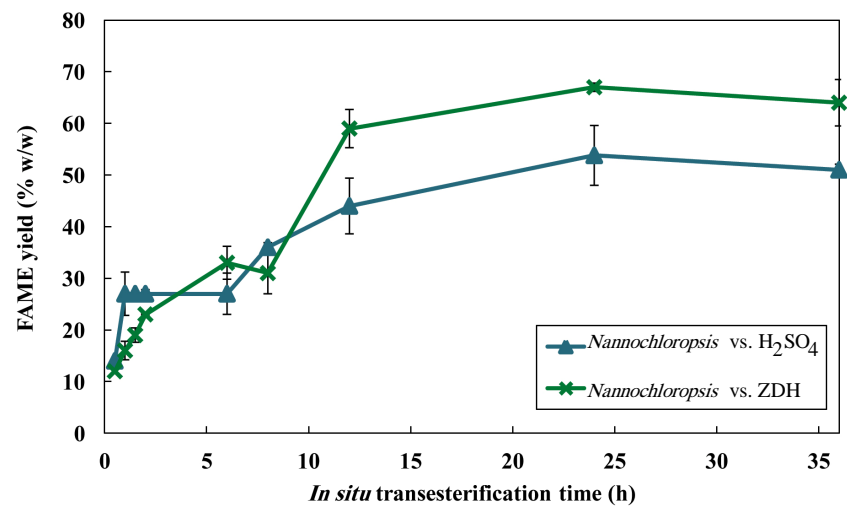

Fig.3. Reactively extracted FAME profile of Nannochloropsis occulata with $\mathrm{H}_{2} \mathrm{SO}_{4}$ vs ZDS. Process conditions: $600 \mathrm{~mol}$ methanol $/$ (mol lipids) $=0.47 \mathrm{~mL}$ methanol $/(\mathrm{mg}$ algae), $8.5 \mathrm{~mol} \mathrm{H}_{2} \mathrm{SO}_{4} /$ (mol lipids) $=0.087 \mu \mathrm{L} /(\mathrm{mg}$ algae), $100 \% \mathrm{ZDS}$ (w/w lipids), mass of microalgae $=100 \mathrm{mg}$, agitation rate $=450 \mathrm{rpm}$, temperature $=60^{\circ} \mathrm{C}$.

\subsection{Mechanisms of enhancement of FAME yield by the ZDS catalyst}

The differences in the FAME production by the different catalysts used could be explained in terms of the chlorophyll extracts after the in situ transesterification, as shown in Table 1.

Table 1.

Chlorophyll content as a measure of cell disruption in Nannochloropsis occulata.

\begin{tabular}{lcl}
\hline Catalyst & Total chlorophyll $(\mu \mathrm{g} / \mathbf{m L})$ & $\begin{array}{c}\text { Statistical analysis } \\
(\mathbf{P}, \boldsymbol{t} \text { tests })\end{array}$ \\
\hline Control experiment & $0.59 \pm 0.02$ & - \\
Acid & $2.68 \pm 0.12$ & 0.01 \\
Acid+SDS & $2.74 \pm 0.19$ & 0.03 \\
ZDS & $2.90 \pm 0.29$ & 0.03 \\
\hline
\end{tabular}

Total chlorophyll, i.e., chlorophyll A+C. Process conditions: $600 \mathrm{~mol} \mathrm{methanol} /(\mathrm{mol}$ lipids) $=0.47 \mathrm{~mL}$ methanol, $8.5 \mathrm{~mol} \mathrm{H}_{2} \mathrm{SO}_{4} /$ (mol lipids) $=0.087 \mu \mathrm{L} \quad \mathrm{H}_{2} \mathrm{SO}_{4} /(\mathrm{mg}$ algae), agitation $=450 \mathrm{rpm}$, temperature $=32^{\circ} \mathrm{C}$ mass of microalgae $=100 \mathrm{mg}$, mass of $\mathrm{SDS}=9 \mathrm{mg}, 100 \% \mathrm{ZDS} /(\mathrm{w} / \mathrm{w}$ lipids $)$, reaction time $=24 \mathrm{~h}$. The control experiment contained no catalyst but other conditions were the same.

Chlorophyll concentration has been positively correlated with cell wall disruption (Gerde et al., 2012). Based on this measurement, $\mathrm{H}_{2} \mathrm{SO}_{4}$, $\mathrm{H}_{2} \mathrm{SO}_{4}+\mathrm{SDS}$, and ZDS significantly disrupted the cells (i.e. $\mathrm{p}<0.05$ ) than the control experiment but there was no significant differences in cell wall disruption between $\mathrm{H}_{2} \mathrm{SO}_{4}$ and $\mathrm{H}_{2} \mathrm{SO}_{4} \mathrm{SDS}$ even though there was a significant difference between the FAME yields as presented in Table 2. However, the highest chlorophyll extract was produced when using ZDS Clearly, ZDS disrupted $N$. occulata's cell wall more effectively than $\mathrm{H}_{2} \mathrm{SO}_{4}$ which explains why it produced greater FAME yield than $\mathrm{H}_{2} \mathrm{SO}_{4}$ alone.

$\mathrm{H}_{2} \mathrm{SO}_{4}$ concentrations of 8.5 and $15 \mathrm{~mol} /(\mathrm{mol}$ lipids) were equivalent to 0.326 and $0.578 \mathrm{mmol} \mathrm{H}^{+}$, respectively. Increase in $\mathrm{H}_{2} \mathrm{SO}_{4}$ concentration from 8.5 to $15 \mathrm{~mol} /(\mathrm{mol}$ lipids) resulted in increases in FAME production rate. The maximum FAME yield produced at $15 \mathrm{~mol} /(\mathrm{mol}$ lipids) was greater than that produced by ZDS. However, $100 \%$ ZDS (w/w lipids) used was equivalent to $0.0624 \mathrm{mmol} \mathrm{H}^{+}$indicating that ZDS was more efficient on a mass for mass basis than $\mathrm{H}_{2} \mathrm{SO}_{4}$ catalyst. The highest FAME yield $(98 \%)$ was obtained using $\mathrm{SDS}+\mathrm{H}_{2} \mathrm{SO}_{4}$ at $20 \%$ moisture content in 
the microalgae indicating that moisture did not adversely affect this process at this level when catalyst/surfactant was used.

Table 2 .

Maximum FAME yields from Nannochloropsis occulata.

\begin{tabular}{lcc}
\hline Catalyst & $\begin{array}{c}\text { FAME yield } \\
\text { \% (w/w) }\end{array}$ & $\begin{array}{c}\text { Reaction time } \\
\text { (h) }\end{array}$ \\
\hline${ }^{\mathrm{a}} \mathrm{H}_{2} \mathrm{SO}_{4}$ & $54 \pm 8$ & 24 \\
${ }^{\mathrm{b}} \mathrm{H}_{2} \mathrm{SO}_{4}$ & $87 \pm 2$ & 24 \\
$\mathrm{SDS}^{\mathrm{a}}{ }^{\mathrm{H}} \mathrm{H}_{2} \mathrm{SO}_{4}$ & $73 \pm 7.7$ & 24 \\
$\mathrm{SDS}+{ }^{\mathrm{b}} \mathrm{H} 2 \mathrm{SO} 4$ & $98 \pm 6.7$ & 24 \\
$\mathrm{ZDS}$ & $67 \pm 1$ & 24 \\
\hline
\end{tabular}

${ }^{\mathrm{a}} \mathrm{H} 2 \mathrm{SO} 4=8.5 \mathrm{~mol} /(\mathrm{mol} \mathrm{lipids}) ;{ }^{\mathrm{b}} \mathrm{H}_{2} \mathrm{SO}_{4}=15 \mathrm{~mol} /(\mathrm{mol}$ lipids $) ; \mathrm{SDS}+{ }^{\mathrm{a}} \mathrm{H}_{2} \mathrm{SO}_{4}$ for dry algae; SDS $+{ }^{b} \mathrm{H}_{2} \mathrm{SO}_{4}$ for wet algae at $20 \%$ moisture (w/w dry algae). Process conditions: $600 \mathrm{~mol}$ methanol $/(\mathrm{mol}$ lipids $)$, agitation rate $=450 \mathrm{rpm}$, temperature $=60^{\circ} \mathrm{C}$, mass of microalgae $=100$ $\mathrm{mg}$, mass of SDS $=9 \mathrm{mg}, 100 \%$ ZDS (w/w lipids).

\subsection{Effect of inclusion of SDS in $\mathrm{H}_{2} \mathrm{SO}_{4}$ on water tolerance}

It has been shown that acid-catalysed direct transesterification exhibits higher water tolerance to microalgae-bound water (Velasquez-Orta et al., 2013) and free water (Wahlen et al., 2011). In order to investigate the level of water tolerance of $\mathrm{H}_{2} \mathrm{SO}_{4}$, with and without SDS, samples with 10, 20, and 30 $\%$ distilled water (w/w dry algae) were prepared and allowed to equilibrate for $1 \mathrm{~h}$. Surprisingly, there was an increase in the FAME rate for $\mathrm{H}_{2} \mathrm{SO}_{4}$, with or without SDS, with increase in moisture content in the algae as shown in Figure 4.

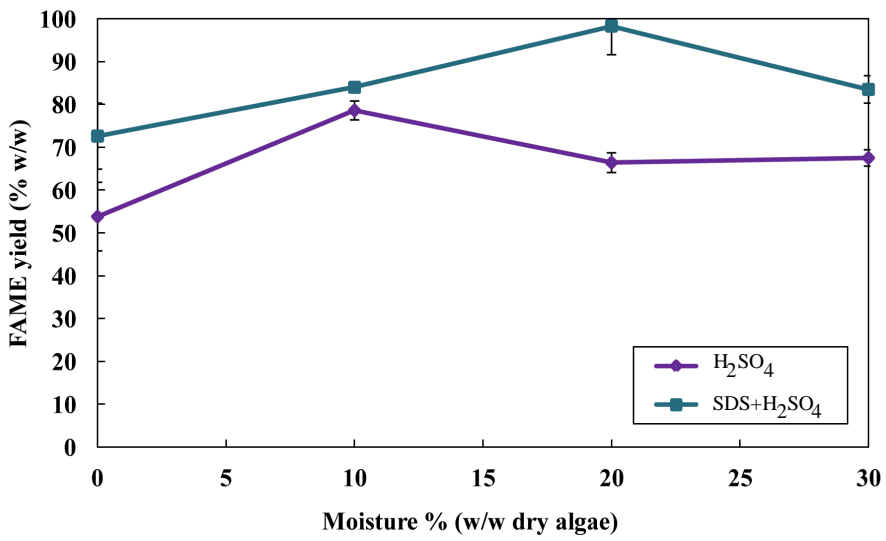

Fig.4. Reactively Extracted FAME produced from re-hydrated Nannochloropsis occulata with $\mathrm{H}_{2} \mathrm{SO}_{4}$ or $\mathrm{H}_{2} \mathrm{SO}_{4}+\mathrm{SDS}$. Process conditions: $600 \mathrm{~mol}$ methanol $/($ mol lipids $)=0.47 \mathrm{~mL}$ methanol, $8.5 \mathrm{~mol} \mathrm{H} \mathrm{H}_{2} \mathrm{SO}_{4} /(\mathrm{mol}$ lipids $)=0.087 \mu \mathrm{L} /(\mathrm{mg}$ biomass $)$, agitation $=450 \mathrm{rpm}$, temperature $=60^{\circ} \mathrm{C}$, mass of SDS $=9 \mathrm{mg}$, mass of microalgae $=100 \mathrm{mg}$.

The FAME production rates begin to decrease at $30 \%$ moisture content. Cell wall lipids, such as phospholipids and glycolipids may be disrupted by polar organic solvents such as methanol, ethanol, other alcohols, and water (Cohen et al., 2012). However, the poor permeability of these solvents into the cells of completely dry oil-bearing biomass can significantly reduce their lipid extraction efficiency (Cohen et al., 2012). This can be counteracted to some extent by addition of a small quantity of water, as it swells the cell wall. The inclusion of water in extracting solvents including methanol or ethanol has been reported to increase extraction of phospholipids (Zhukov and Vereshchagrin, 1981). Removal of the cell wall lipids (phospholipids and glycolipids) from the algal cell walls compromises their integrity, i.e., it disrupts the cell wall to some degree thereby increasing accessibility of the solvent (methanol) to the internal body lipids (triglycerides). In addition, the interaction of water and methanol with cell wall proteins could compromise their integrity. The enhancement observed in the present study could be some combination of these two effects and the swelling effect. Therefore, the observed water tolerance in the re-hydrated microalgae was probably due to increased lipid extraction by moist methanol. This could be a key method of increasing the FAME yield in in situ transesterification of wet microalgae.
However, beyond $20 \%$ moisture content, a drop in the FAME yield was observed, which showed that the water tolerance was exceeded for both catalysts. The amount of water tolerance achieved herein was greater than $10 \%$ (w/w dry mass) obtained by Velasquez-Orta et al. (2013), perhaps because their moisture content was based on bound, rather than the free water used in this current investigation. However, the water tolerance achieved herein was lower than the $50 \%$ (w/w dry mass) of free water during acid-catalysed in situ esterification of $C$. gracilius reported by Wahlen et al. (2011). It was also lower than the $80 \%$ (w/w dry mass) of free water during acid-catalysed in situ transesterification of $N$. gaditana reported by Kim et al. (2015). It should be noted that Wahlen et al. (2011) used $0.04 \mathrm{~mL}$ methanol/(mg algae) while Kim et al. (2015) used $0.01 \mathrm{~mL}$ methanol/(mg algae). These methanol volumes/(mg algae) were significantly higher than the $0.0047 \mathrm{~mL} /(\mathrm{mg}$ algae $)$ used in this study Therefore, their corresponding higher water tolerance than what observed herein is expected. In situ esterification of microalgae using $\mathrm{H}_{2} \mathrm{SO}_{4}$ as catalyst exhibited the same water tolerance, with or without SDS. However, the inclusion of SDS in $\mathrm{H}_{2} \mathrm{SO}_{4}$ produced greater FAME yields than $\mathrm{H}_{2} \mathrm{SO}_{4}$ alone at each moisture content as shown in Figure 4.

Park et al. (2014) has shown that the inclusion of sodium dodecyl benzene sulfonate (SDBS) in $\mathrm{H}_{2} \mathrm{SO}_{4}$ enhanced the extraction of FFAs and lipids from Chlorella. They also reported that SDS did not produce the same corresponding enhancement as SDBS (Park et al., 2014). It should be noted that their experiments were fundamentally different from what is reported herein. They investigated the effect of the inclusion of SDBS or SDS in $\mathrm{H}_{2} \mathrm{SO}_{4}$-catalysed hot water on the extraction of FFAs and lipids from $C$. vulgaris. They conducted additional experiments on the effect of including SDBS in $\mathrm{H}_{2} \mathrm{SO}_{4}$ for FAME production from the pre-extracted algal oil through a two-step transesterification. In better words, the approach used by Park et al. (2014) involved making biodiesel from preextracted algal oil which is fundamentally different from the single step transesterification ("in situ transesterification") reported in this study.

\section{Conclusions}

In situ transesterification has been shown to be technically feasible for FAME production from $N$. occulata using $\mathrm{H}_{2} \mathrm{SO}_{4}, \mathrm{H}_{2} \mathrm{SO}_{4} / \mathrm{SDS}$ (a surfactant), or ZDS (surfactant catalyst). ZDS produced a maximum $67 \pm 1$ $\%$ FAME yield. SDS addition to $\mathrm{H}_{2} \mathrm{SO}_{4}$ enhanced the FAME yield and caused some levels of water tolerance. Addition of SDS in $\mathrm{H}_{2} \mathrm{SO}_{4}$ at $20 \%$ moisture content produced a maximum FAME yield of $98.3 \pm 6.7 \%$. Finally, not only the process was more tolerant to water than transesterification-based routes, but the presence of a small quantity of external water increased the FAME yields in in situ transesterification, rather than inhibiting the reaction. This effect was apparent for all conditions up to $20-30 \%$ water (w/w dry algae) which was significantly greater than the maximum of $0.5 \%$ water (w/w oil) required in a two-step transesterification.

\section{References}

[1] Brown, R.B, Audet, J., 2008. Current techniques for single-cell lysis. J. R. Soc. Interface. 5, S131-S138

[2] Canakci, M., Gerpen, V.J., 1999. Biodiesel production via acic catalysis. Trans. ASAE. 42 (5),1203-1210.

[3] Chen L., Tianzhong L., Zhang, W., Chen X., Wang, J., 2012 Biodiesel production from algae oil high in free fatty acids by twostep catalytic conversion. Bioresour. Technol. 111, 208-214.

[4] Chisti Y., 2007. Biodiesel from microalgae. Biotechnol. Adv. 25(3) 294-306.

[5] Chisti, Y., 2013. Constraints to commercialization of algal fuels. J Biotechnol. 167, 201-214

[6] Cohen, Z., 1999. Chemicals from microalgae, CRC Press.

[7] Ehimen, E.A., Sun, Z.F., Carrington, C.G., 2010. Variables affecting the in situ transesterification of microalgae lipids. Fuel. 89 (3), 677 684.

[8] El-Shimi, H.I., Attia, N.K., El-Sheltawy, S.T., El-Diwani, G.I., 2013. Biodiesel production from Spirulina-platensis microalgae by in-situ transesterification process. J. Sust. Bioenerg. Syst. 3, 224233. 
[9] Standard UNE-EN 14103, 2003. Determination of ester and linolenic acid methyl ester contents. Issued by Asociación Española de Normalización y Certificación, Madrid.

[10] Eze, V.C., Phan, A.N., Harvey, A.P., 2014. A more robust model of biodiesel reaction, allowing identification of process conditions for enhanced rate and water tolerance. Bioresour. Technol. 156, 222-231.

[11] Folch, J., Lees, M., Stanley, G.H.S., 1956. A simple method for the isolation and purification of total lipids from animal tissue. J. Biol. Chem. 1, 497-509.

[12] Garces, R., Mancha, M., 1993. One-step lipid extraction and fatty acid methyl esters preparation from fresh plant tissues. Anal Biochem. 211, $139-143$.

[13] Gerde, J.A., Montalbo-Lomboy, M., Yao, L., Grewell, D., Wanga, T., 2012. Evaluation of microalgae cell disruption by ultrasonic treatment. Bioresour. Technol. 125, 175-181.

[14] Gerken, H.G., Donohoe, B., Knoshaug, E.P., 2012. Enzymatic cell wall degradation of Chlorella vulgaris and other microalgae for biofuels production. Planta. 1, 239-253.

[15] Ghesti, G.F., Macedo, J.L., Parente, V.C.I., Dias, J.A., Dias, S.C.L., 2009. Synthesis, characterization and reactivity of Lewis acid/surfactant cerium trisdodecylsulfate catalyst for transesterification and esterification reactions. Appl. Catal, A. 355(1), 139 -147.

[16] Guldhe, A., Singh, B., Rawat, I., Ramluckan, K., Bux, F., 2014. Efficacy of drying and cell disruption techniques on lipid recovery from microalgae for biodiesel production. Fuel. 128, 46-52.

[17] Haas, M.J., Wagner, K., 2011. Simplifying biodiesel production:The direct or in situ transesterification of algal biomass. Eur. J. Lipid Sci. Technol. 113, 1219-1229.

[18] Hailegiorgis, S.M., Mahadzir, S., Subbarao, D., 2011. Enhanced in situ ethanolysis of Jatropha curcas L. in the presence of cetyltrimethylammonium bromide as a phase transfer catalyst. Renew. Energ. 36, 2502-2507.

[19] Jeffery, S.W., Humphrey, G.F., 1975. New spectrophotometric equations for determining chlorophylls $a, b, c_{1}$, and $c_{2}$ in higher plants, algae and natural phytoplankton. Biochem. Physiol. Pflanz. 167,191194.

[20] Kaluzny, M.A., Duncan, L.A., Merritt, M.V., Epps, D.E., 1985. Rapid separation of lipid classes in high yield and purity using bonded phase columns. J. Lipid Res. 26, 135-140.

[21] Kasim, F.H., Harvey, A.P., 2011. Influence of various parameters on reactive extraction of Jatropha curcas L. for biodiesel production. Chem. Eng. J. 171, 1373-1378.

[22] Kim, B., Im, H., Lee, J.W., 2015. In situ transesterification of highly wet microalgae using hydrochloric acid. Bioresour. Technol. 185, 421 425 .
[23] Li, Y., Lian, S., Tong, D., Song, R., Yang, W., Fan, Y., Qing, R., $\mathrm{Hu}, \quad \mathrm{C} ., 2011$. One-step production of biodiesel from Nannochloropsis sp. on solid base Mg-Zr catalyst. Appl. Energy. 88 (10), 3313-3317.

[24] Lotero, E., Liu, Y., Lopez, D.E., Suwannakarn, K., Bruce, D.A., Goodwin, J.G., 2005. Synthesis of biodiesel via acid catalysis. Ind. Eng. Chem. Res. 44, 5353-5363.

[25] Ma, F., Hanna, M.A., 1999. Biodiesel production: a review. Bioresour. Technol.70, 1-15.

[26] Meng, X., Yang, J., Xu, X., Zhang, L., Nie, Q., Xian, M., 2009 Biodiesel production from oleaginous microorganisms. Renew. Energy. 34, 1-5.

[27] Park, J.Y., Nam, B., Choi, S.A., Oh, Y.K., Lee, J.S., 2014. Effects of anionic surfactant on extraction of free fatty acid from Chlorella vulgaris. Bioresour. Technol. 166, 620-624.

[28] Tan, A., Ziegler, A., Steinbauer, B., Seelig, J., 2002. Thermodynamics of sodium decyl sulfate partitioning into lipid membranes. Biophys. J. 83, 1547-1556.

[29] Tuntiwiwattanapun, N., Tongcumpou, C., Haagenson, D. Wiesenborn, D., 2013. Development and Scale-up of Aqueous Surfactant-Assisted Extraction of Canola Oil for Use as Biodiesel Feedstock. J. Am. Oil Chem. Soc. 90(7), 1089-1099.

[30] Velasquez-Orta, S.B., Lee, J.G.M., Harvey, A., 2012. Alkaline in situ transesterification of Chlorella vulgaris. Fuel. 94, 544-550.

[31] Velasquez-Orta, S.B., Lee, J.G.M., Harvey, A.P., 2013. Evaluation of FAME production from wet marine and freshwater microalgae by in situ transesterification. Biochem. Eng. J. 76, 83-89.

[32] Wahlen, B.D, Willis, R.M, Seefeldt, L.C., 2011. Biodiese production by simultaneous extraction and conversion of total lipids from microalgae, cyanobacteria, and wild mixed-cultures. Bioresour. Technol. 102(3), 2724-2730.

[33] Widjaja, A., Chien, C., Ju, Y., 2009. Study of increasing lipid production from fresh water microalgae Chlorella vulgaris. J. Taiwan Inst. Chem. Eng. 40, 13-20.

[34] Zeng, J., Wang, X., Zhao, B., Sun, J., Wan, Y., 2008. Rapid in situ transesterification of sunflower oil. Ind. Eng. Chem. Res. 48 (2), 850-856.

[35] Zhukov, A.V., Vereshchagrin, A.G., 1981. Current Techniques of extraction, purification and preliminary fractionation of polar lipids of natural origin. Adv. Lipids Res. 18, 247-282.

[36] Zolfigol, M.A., Salehi, P., Shiri, M., Tanbakouchian, Z., 2007. A new catalytic method for the preparation of bis-indolyl and trisindolyl methanes in aqueous media. Catal. Commun. 8, 173-178. 